\title{
Severe ciliopathy-related phenotypes in mice with dysregulation of tubulin polyglutamylation
}

\author{
K Ikegami*, A Konno, S Hattori, C Matsuda, M Setou \\ From First International Cilia in Development and Disease Scientific Conference (2012) \\ London, UK. 16-18 May 2012
}

Tubulin, a main component of ciliary and flagellar axonemes, undergoes highly unique post-translational modifications, polyglutamylation and polyglycylation. Recent years, evidence accumulates that dysregulations of these two modifications lead to severe ciliary defects in a variety of model organisms, such as Chlamydomonas, Tetrahymena, C. elegans, Drosophila, and zebrafish. Previously, we have for the first time revealed that a reduction of tubulin polyglutamylation causes ciliopathy-related defects including severe respiratory problems, such as paranasal sinusitis and repetitive coughing or sneezing, and male infertility by means of a knockout mouse of a glutamate ligase (TTLL1KO) [Ikegami et al. 2010 PNAS]. Despite the clear ciliopathy-related defects by the loss of polyglutamylation-performing enzyme, it is still veiled whether over-polyglutamylation leads to ciliopathyrelated phenotypes in mice. To address the question, we examined the retina of a spontaneous mutant of a glutamate-removing enzyme $(p c d)$ mouse that displays lateonset retinal photoreceptor degeneration. The $p c d$ mouse showed stronger polyglutamylation signals in the retinal cone and rod layer compared to wild-type animal. To test if the hyper-polyglutamylation leads to retinal degeneration, we generated a double mutant of $p c d$ and TTLL1KO. The hyper-polyglutamylation observed in the cone and rod layer of $p c d$ mice was neutralized in that of $p c d /$ TTLL1KO double mutant. The retinal photoreceptor degeneration in $p c d$ was almost completely rescued in the pcd/TTLL1KO double mutant. These results suggest that hyper-polyglutamylation underlies retinal photoreceptor degeneration. We would emphasize, in the conference, the importance of keeping narrow range of polyglutamylation level to maintain ciliary function.

\footnotetext{
* Correspondence: kikegami@hama-med.ac.jp

Hamamatsu University School of Medicine, Japan
}

Published: 16 November 2012

doi:10.1186/2046-2530-1-S1-P90

Cite this article as: Ikegami et al:: Severe ciliopathy-related phenotypes in mice with dysregulation of tubulin polyglutamylation. Cilia 2012 1(Suppl 1):P90.
Submit your next manuscript to BioMed Central and take full advantage of:

- Convenient online submission

- Thorough peer review

- No space constraints or color figure charges

- Immediate publication on acceptance

- Inclusion in PubMed, CAS, Scopus and Google Scholar

- Research which is freely available for redistribution
() Bïmed Central
C Biomed Central 